https://jurnal.unigal.ac.id/index.php/jall/index

JALL (Journal of Applied Linguistics and Literacy), ISSN 2598-8530, September, Vol. 4 No. 2, 2020

\begin{tabular}{|ccc|}
\hline Received & Accepted & Published \\
\hline August 2020 & September 2020 & September 2020 \\
\hline
\end{tabular}

\title{
THE STUDENTS' LEARNING ACHIEVEMENT AFTER AND WITHOUT STUDYING ENGLISH IN ELEMENTARY SCHOOL
}

\author{
Gusri Emiyati Ali \\ gusri@poliupg.ac.id \\ Politeknik Negeri Ujung Pandang
}

\begin{abstract}
The Critical Period Hypothesis by Lenneberg (1976) states that ages 2 to 12 are ideal ages for achieving foreign language skills such as a native speaker. Based on this hypothesis, the perfect time for children to learn English as a foreign language is in elementary school. Meanwhile, Indonesian government policy through the 2013 curriculum does not require children in primary schools to learn English. Therefore, this study aimed to compare the English learning achievement of students between those who studied and those who did not study English in elementary school. This research is important to be conducted since it can be a reference for the Indonesian government in developing English language teaching and learning policy in elementary schools. The sample of this research consisted of two groups selected through a purposive sampling technique. They were the group of students who studied and who did not study English in elementary school. Data were grouped, presented, and then compared. The results showed that students who studied English in elementary school had better English learning achievement than students who did not study English in elementary school. It is recommended for further related researches to consider many factors those can be influencing the students' English learning achievement such as the English teaching and learning method used by the educators in high school and university, attitudinal factor, and the learning environment.
\end{abstract}

\section{Keywords: Critical Period Hypothesis, English in elementary school}

\section{INTRODUCTION}

The need for English skills at this time is no doubt. English is one of the important keys to face global competition. As the next generation, of course, students are very important to have good English skills for the nation's development. Besides, they need to be able to compete in the workforce. To have good English language skills, someone who is not a native English speaker like an Indonesian requires a short amount of study time. In language 
learning, there is a hypothesis that considers age as an important factor in achieving language skills. This hypothesis is known as the critical age hypothesis (Critical Age Hypothesis). This hypothesis was born from the observation that children are faster and more successful in picking up a language compared to adults. According to Lenneberg (in Field, 2003), ages 2 to 12 years are ideal for achieving language skills such as native speakers of foreign languages. By referring to Lenneberg's hypothesis, Scovel (in Steinberg, 2006) argues that an adult cannot master a foreign language without losing his primary language accent. Referring to this hypothesis, the ages of an Indonesian child to learn English as a foreign language are ages 2 to 12 years. it can be said that the most appropriate time for Indonesian children to learn English is in elementary school. In line with, Thoyyibah (2019) points out that Indonesian students join extra courses to learn English outside the school setting. However, through the 2013 curriculum, English subject is a no longer compulsory subject for elementary school children (Permendikbud No. $67 \mathrm{Th}$. 2013). They are only required to learn English in middle school and high school. Importunately, according to the hypothesis, at that age, foreign language learning will not be maximized. Referring to the critical age hypothesis and considering the importance of English language skills for students both as prospective job seekers and as the nation's next-generation, the author is interested in finding out if there are differences in English learning achievement of students who study English in elementary school and those that do not. It is expected that the results of this study can be one of the considerations in determining policies related to English language teaching policy in elementary schools.

\section{METHOD}

This research was a comparative descriptive study. The approach used was quantitative where the analysis of the research is more focused on numerical data (numbers) that are processed using statistical methods (Azwar: 2012). The population of this study was all students who studied and who did not study English in elementary school on condition that they had never taken an English course. Data were taken from the students' scores in the same English subject and with the same lecturer. It was then analyzed quantitatively, and the results were described descriptively. This research 
instrument was an open questionnaire to collect the data. Data were collected and grouped into four categories, namely, very satisfactory category (value A), satisfactory (B + and B) sufficient (C+ and C), less (D), and very less (E). After the English scores of the two groups of samples were categorized, then were compared.

\section{FINDINGS AND DISCUSSION}

The followings are the percentage of students' learning achievements in English subject of both groups of samples.

Table 1. Percentage of English learning achievement of students who studied and those who did not study English in elementary school

\begin{tabular}{|c|c|c|c|}
\hline No & Score & Sample Group 1 & Sample Group 2 \\
\hline 1 & A & $49.48 \%$ & $29.17 \%$ \\
\hline 2 & B + & $21.65 \%$ & $33.33 \%$ \\
\hline 3 & B & $24.74 \%$ & $29.17 \%$ \\
\hline 4 & C & $1.03 \%$ & $4.17 \%$ \\
\hline 5 & C & $3.09 \%$ & $4.17 \%$ \\
\hline 6 & D & $0 \%$ & $0,00 \%$ \\
\hline
\end{tabular}

\section{Information:}

Sample Group 1: Sample group who studied English in elementary school

Sample Group 2: Sample group that did not study English in elementary school

To see the comparison between English learning achievement of students who study and those who did not study English in elementary school, the following data from both are presented in a bar diagram. 


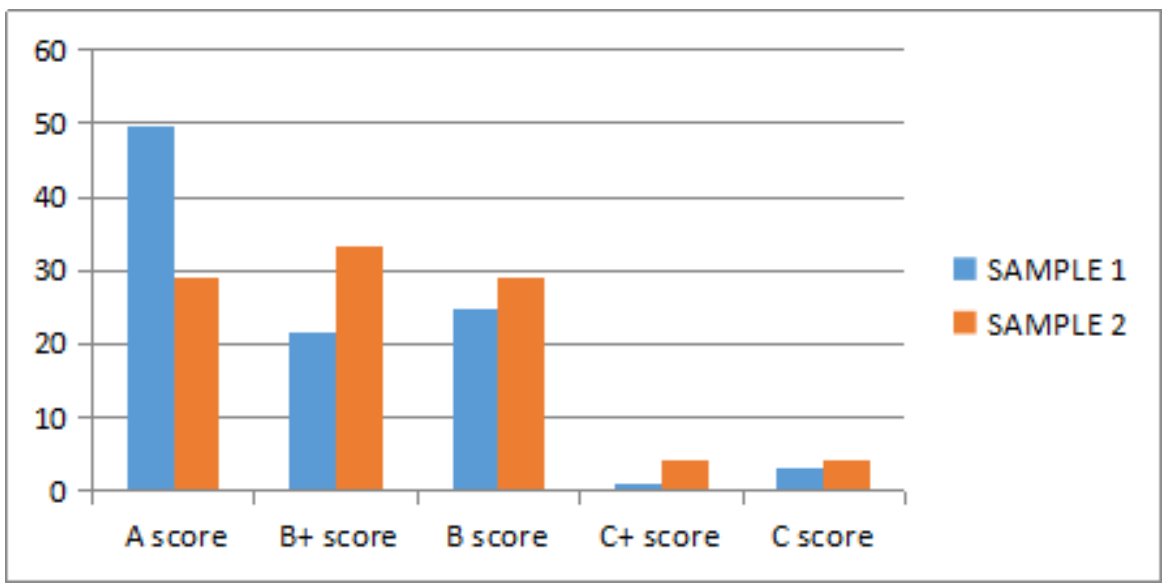

Based on the results of data processing obtained from the questionnaire, it can be seen the comparison of students' English learning achievement between those who studied and those who did not study English in elementary school. Nearly half of the total sample or $48.48 \%$ of students who have studied English in elementary school got a very satisfactory score or A score. This percentage is higher than the number of students who did not study English in primary school which is only by $29.17 \%$ received A score in the same subject with the same lecturer.

For moderate score or $\mathrm{B}+$ and $\mathrm{B}$ scores, the results of data processing showed that the number of students who did not study English in primary school got more than the number of students who studied English in primary school, but with a very small difference. For students who did not study English in elementary school, there were 33.33\% who received B+ score and 29.17\% who received B score. For students who studied English in Elementary school, there were $21.65 \%$ who got B+ score and $24.74 \%$ who got B.

Meanwhile, the low score or $\mathrm{C}+$ and $\mathrm{C}$ scores were obtained more by students who did not study English in elementary school. There were $4.17 \%$ of students who received C+ score and there were $4.17 \%$ of them who got $\mathrm{C}$ score. For students who studied English in primary school, there were only $1.09 \%$ who got $\mathrm{C}+$ score and there were $3.09 \%$ who got $\mathrm{C}$.

\section{CONCLUSIONS}

From the data that have been obtained and analyzed, it can be concluded that the English learning achievement of students who studied English in primary school is better than the English learning achievement of students who did not study English in primary school. This 
is evidenced by the greater number of students who studied English in primary school got high score (A) compared to those who did not study English in primary school. There are fewer students who studied English in primary school got low score $(\mathrm{C}+$ and $\mathrm{C})$ compared to those who did not study English in elementary school. It is recommended for further related researches to consider many factors those can be influencing the students' English learning achievement such as the English teaching and learning method used by the educators in high school and university, attitudinal factor, and the learning environment.

\section{REFERENCES}

Aan, Komariah dan Djam'an Satori. (2010). Metodologi Penelitian Kualitatif Bandung: Alfabeta.

Agung, Iskandar. (2010). Meningkatkan Kreativitas Pembelajaran bagi Guru. Jakarta. Akdon dan Ridwan. (2013). Rumus dan Data dalam Analisis Statistika. Bandung: Alfabeta

Ali, M. (2010). Metodologi dan Aplikasi Riset Pendidikan. Bandung: Pustaka Cendikia Utama.

Alwi, Hasan. (2007). KBBI, edisi ketiga. Jakarta: Balai Pustaka.

A.M, Sardiman. (2000). Interaksi \& Motivasi Belajar Mengajar. Jakarta: Rajawali. Pers.

Azwar, S. (2012). Metode Penelitian. Yogyakarta: Pustaka Pelajar.

Brown, H. G. (2001). Teaching by Principles: Interactive Approach to Language. Pedagogy. New York : San Francisco State University

Djamarah, Syaiful Bahri. (2011). Psikologi Belajar. Jakarta : Rineka Cipta

Djalal, M.F. (2006). Penilaian Dalam Pengajaran Bahasa Asing. Malang: P3T IKIP Malang

Field, John. (2003). Psycholinguistics A Resource Book For Students. Routledge Taylor\& Francis Group.

Hamdu, Ghullam. (2011). "Pengaruh Motivasi Belajar Siswa Terhadap Prestasi Belajar IPA Di Sekolah Dasar'. Jurnal Penelitian Pendidikan Vol. 12 No. 1 ISSN 141256.X 
Thoyyibah, L. (2019). Students Background Towards Learning English Out of Classroom Setting. JALL (Journal of Applied Linguistics and Literature), 54-60.

Permendikbud No. 67. (2013). Kerangka Dasar dan Struktur Kurikulum Sekolah Dasar/Madrasah Ibtidaiyah.

Santrock, J.W. (2004). Educational Psychology 2nd ed. New York: McGraw-Hill Companies, Inc.

Steinberg, Danni. D \& Natalia. V. Sciarini. (2006). An Introduction to Psicolinguistics. Pearson Education Limited. Britain.

Sugiyono, (2008). Metode Penelitian Kunatitatif Kualitatif dan R\&D. Bandung. Alfabeta.

Suryabrata, Sumadi. (2004). Psikologi Pendidikan. Jakarta : Raja Grafindo.

Gulo, W. (2002). Strategi Belajar-Mengajar. Jakarta: PT. Gramedia Widiasarana. Indonesia.

Slavin, robert E. (2009). Cooperative Learning (Teori, Riset, Praktik). Bandung: Nusa Media.

Sukmadinata, N.S. (2011). Metode Penelitian Pendidikan. Bandung: Remaja Rosadakarya

Troike, Saville. (2006). Introducing Second Language Acquisition. Cambridge University Press: Cambridge 